Received: 29 Agustus 2020

Revised: 3 November 2020

Accepted: 18 Desember 2020

Published: 31 Desember 2020

\title{
Penerapan Multiple Overlapping Deprivation Analysis dalam Pembentukan Indeks Kemiskinan Multidimensi Anak di Kalimantan Barat
}

\author{
Arif Rahman ${ }^{1, \text { a) }}$, Mohammad Fathan Romdhoni ${ }^{2, \text { b) }}$ \\ ${ }^{1}$ Badan Pusat Statistik Kabupaten Sekadau, Jalan Merdeka Timur Km 09, Komp. Perkantoran Pemda Sekadau \\ ${ }^{2}$ Badan Pusat Statistik Provinsi Kalimantan Barat, Jalan Sutan Syahrir No. 24/42 Pontianak \\ Email: a)rahman.arif@bps.go.id, ${ }^{\text {b)}}$ fathan@bps.go.id
}

\begin{abstract}
Poverty is one of the development problems which is still the main focus for every country. According to Central Bureau of Statistics (BPS), in 2016 the poverty rate in the child age group was the highest. So far, child poverty measure usually drawn from the household poverty where the child lives. Thus, a child who lives in a non poor household is considered to be not poor either. In fact, the characteristics of child poverty are different from household poverty. In addition, many experts criticize the measurement of poverty from the monetary side because it is considered only able to portray a small part of the poverty problem. The aim of the research is to measure the child poverty in West Kalimantan in a multidimensional manner by using the 2019 National Social and Economic Survey (SUSENAS) data. The used method is the Multiple Overlapping Deprivation Analysis (MODA) with 6 dimensions of child poverty including housing, facilities, food and nutrition, education, child protection and health. The result shows that around $14.87 \%$ of children in West Kalimantan are multi-dimensionally poor with the average deprivation experienced are $40.88 \%$ of the 12 indicators forming the index. The dimension that contributes the most to the child poverty in West Kalimantan is the housing dimension. Furthermore, the regency with the highest child multidimensional poverty index (MPI) are Melawi, Sekadau, Sintang, Kapuas Hulu, and Landak.
\end{abstract}

Keywords: child poverty, child MPI, MODA.

\begin{abstract}
Abstrak
Kemiskinan merupakan salah satu masalah pembangunan yang masih menjadi fokus utama bagi setiap negara. Menurut BPS, pada tahun 2016 tingkat kemiskinan pada kelompok umur anak adalah yang paling tinggi. Selama ini, pengukuran kemiskinan anak biasanya masih menggunakan ukuran kemiskinan rumah tangga dimana tempat anak tersebut tinggal. Dengan demikian, anak yang tinggal pada rumah tangga miskin maka akan dianggap miskin, dan begitu juga sebaliknya. Padahal, karakteristik kemiskinan anak berbeda dengan kemiskinan rumah tangga. Selain itu, banyak pakar yang memberikan kritik terhadap pengukuran kemiskinan dari sisi moneter karena dianggap hanya mampu memotret sebagian kecil dari persoalan kemiskinan. Penelitian ini bertujuan untuk mengukur tingkat kemiskinan anak di Kalimantan Barat secara multidimensi menggunakan data Survei Sosial dan Ekonomi Nasional (Susenas) tahun 2019. Metode yang digunakan adalah Multiple Overlapping Deprivation Analysis (MODA) dengan 6 dimensi kemiskinan anak meliputi perumahaan, fasilitas, makanan dan nutrisi, pendidikan, perlindungan anak serta kesehatan. Hasil penelitian menunjukkan bahwa sekitar 14,87\% di Kalimantan Barat miskin secara multidimensi dengan rata-rata deprivasi yang dialami ialah 40,88\% dari 12 indikator yang membentuk
\end{abstract}


indeks. Dimensi yang paling berkontribusi terhadap kemiskinan anak di Kalimantan Barat adalah dimensi perumahan. Selanjutnya, kabupaten dengan indeks kemiskinan multidimensi (IKM) anak tertinggi adalah Melawi, Sekadau, Sintang, Kapuas Hulu, dan Landak.

Kata-kata kunci: kemiskinan anak, IKM anak, MODA.

\section{PENDAHULUAN}

Kemiskinan merupakan salah satu masalah pembangunan yang masih menjadi fokus utama bagi setiap negara. Upaya pengentasan kemiskinan telah menjadi komitmen bersama oleh negara-negara di dunia tak terkecuali Indonesia. Pada tahun 2015, ada sebanyak 193 kepala negara dan pemerintah dunia hadir dalam sidang umum Perserikatan Bangsa-Bangsa (PBB) untuk menyepakati agenda pembangunan universal baru yang dikenal dengan Sustainable Development Goals (SDGs) (Panuluh dan Fitri, 2016). Adapun salah satu tujuan dari kesepakatan tersebut yaitu mengakhiri segala bentuk kemiskinan pada tahun 2030 atau selama 15 tahun kedepan.

Saat ini, metode yang paling umum digunakan oleh banyak negara termasuk Indonesia untuk mengukur tingkat kemiskinan yaitu dengan pendekatan moneter. Berdasarkan pendekatan tersebut, kemiskinan dipandang sebagai ketidakmampuan dari sisi moneter untuk memenuhi kebutuhan dasar makanan dan bukan makanan yang diukur dari sisi pengeluaran. Namun, banyak pakar yang memberikan kritik terhadap pendekatan tersebut, salah satunya peraih nobel ekonomi tahun 1998 yaitu Amartya Sen. Menurutnya, pendekatan dari sisi moneter hanya mampu memotret sebagian kecil dari persoalan kemiskinan (Sen, 1981). Akibatnya, kebijakan pengentasan kemiskinan yang dibuat menjadi tidak tepat dan kurang efektif.

Menurut BPS (2017), pada tahun 2016 ada sebanyak 28,01 juta penduduk Indonesia masih hidup dalam kemiskinan. Dari jumlah itu, sekitar 40,22 persen penduduk miskin tersebut masih berada pada usia anak-anak (0-17 tahun). Apabila dibandingkan dengan kelompok umur lainnya, maka tingkat kemiskinan pada kelompok umur anak adalah yang paling tinggi. Hal tersebut menunjukkan bahwa kemiskinan anak adalah kelompok terbesar yang mengisi proporsi kemiskinan di Indonesia. Padahal, anak-anak merupakan kelompok penduduk yang paling rentan merasakan dampak buruk dari kemiskinan karena faktor usia dan ketergantungannya terhadap orang dewasa.

Menurut UNICEF (2016), kemiskinan anak merupakan situasi deprivasi yang dialami oleh anakanak dari segi sumber daya materi, spiritual, dan emosional yang dibutuhkan untuk bertahan hidup, berkembang, dan maju yang menimbulkan keterbatasan dalam menikmati hak-hak yang dimilikinya dan mencapai potensi penuh dalam berpartisipasi sebagai anggota masyarakat. Setiap anak yang tinggal di rumah tangga miskin, dapat memicu hilangnya hak-hak dasar anak. Hal tersebut tentu saja akan mempengaruhi mental, fisik, emosi, dan tingkat spiritual anak. Lebih jauh, anak-anak yang mengalami deprivasi dalam proses tumbuh kembangnya akan berpeluang besar menjadi penduduk dewasa yang tidak produktif, sehingga akan sulit untuk keluar dari jebakan kemiskinan. Oleh karena itu, upaya pengentasan kemiskinan dimulai pada anak-anak penting untuk dilakukan karena investasi pada anak-anak merupakan sesuatu yang penting dalam rangka mencapai tujuan pembangunan manusia yang berkelanjutan.

Selama ini, indikator yang digunakan untuk mewakili kondisi kemiskinan anak masih menggunakan ukuran kemiskinan rumah tangga. Padahal, dalam kenyataannya karakteristik kemiskinan anak berbeda dengan kemiskinan rumah tangga. Hal tersebut karena distribusi ekonomi untuk masing-masing anggota rumah tangga tidaklah sama. Menurut Milliano dan Handa (2014), anak-anak memiliki kebutuhan dasar yang berbeda dengan orang dewasa, tetapi distribusi sumber daya di dalam rumah tangga terkadang tidak merata dan anak-anak lebih cenderung mendapatkan akses yang kurang terhadap sumber daya tersebut dibandingkan dengan orang dewasa. Dengan demikian, dibutuhkan suatu metode yang lebih spesifik untuk menganalisis kondisi kemiskinan pada anak-anak.

Berdasarkan latar belakang permasalahan yang telah diuraikan sebelumnya, maka penelitian terkait kemiskinan anak menggunakan pendekatan yang lebih komprehensif penting untuk dilakukan. Adapun tujuan utama dari penelitian ini adalah untuk mendeskripsikan kemiskinan anak melalui pendekatan multidimensi dengan membentuk suatu Indeks Kemiskinan Multidimensi (IKM) Anak. Tujuan selanjutnya yaitu mengelompokkan kabupaten/kota agar diketahui skala prioritas untuk setiap 
wilayah dalam pengentasan kemiskinan. Sehubungan dengan ketersediaan data dan pemahaman wilayah oleh peneliti, maka fokus penelitian ini hanya mencakup Provinsi Kalimantan Barat pada tahun 2019.

\section{METODOLOGI PENELITIAN}

Jenis data yang digunakan dalam penelitian ini adalah data sekunder berupa raw data hasil Survei Sosial Ekonomi Nasional (Susenas) Maret 2019 dan beberapa data publikasi BPS seperti data Indeks Pembangunan Manusia (IPM) dan data persentase penduduk miskin bulan Maret tahun 2019. Jumlah sampel yang tercakup dalam penelitian ini ialah 11.051 penduduk usia 0-17 tahun yang tersebar di seluruh kabupaten/kota di Provinsi Kalimantan Barat.

Metode analisis yang digunakan terdiri dari Multiple Overlapping Deprivation Analysis (MODA), korelasi rank Spearman, dan klasifikasi kuadran. MODA merupakan suatu pendekatan komprehensif yang digunakan untuk menganalisis aspek multidimensional dari kemiskinan anak yang dikenalkan oleh UNICEF (2011). MODA dibangun berdasarkan pendekatan Bristol dan Multidimensional Poverty Index (MPI) dengan dasar metode Alkire-Foster (AF). Pendekatan ini menekankan bahwa kesejahteraan anak terdiri dari berbagai aspek yang tidak dapat dipisahkan satu dengan yang lain sehingga analisis terhadap deprivasi anak harus menempatkan aspek-aspek tersebut secara simultan. Melalui pendekatan ini dihasilkan Indeks Kemiskinan Multidimensi (IKM) Anak.

Selanjutnya, korelasi rank Spearman digunakan untuk menguji validitas IKM Anak. Korelasi rank Spearman adalah salah satu metode statistik nonparametrik yang digunakan untuk mencari tingkat hubungan atau menguji signifikansi asosiatif bila data dalam masing-masing variabel berskala ordinal (Sedgwick, 2014).

Kemudian, klasifikasi kuadran digunakan untuk mengetahui wilayah mana saja yang perlu menjadi prioritas pemerintah dalam membuat kebijakan terkait upaya pengentasan kemiskinan anak. Klasifikasi kuadran terbentuk dari scatter plot antara IKM Anak (sumbu vertikal) dengan persentase rumah tangga miskin (sumbu horizontal). Nilai cut off IKM Anak yang digunakan adalah IKM Anak provinsi yang ditunjukkan dengan garis horizontal yang memotong tegak lurus sumbu vertikal. Sementara itu, nilai cut off persentase rumah tangga miskin yang digunakan adalah persentase rumah tangga miskin provinsi yang ditunjukkan dengan garis vertikal yang memotong tegak lurus sumbu horizontal.

\section{Penghitungan Indeks Kemisikinan Multidimensi (IKM) Anak}

Menurut UNICEF (2012), dalam penghitungan IKM Anak menggunakan metode MODA, tahap pertama yang dilakukan adalah menentukan unit analisis. Adapun unit analisis yang digunakan dalam penelitian ini ialah individu usia anak (0-17 tahun) yang tinggal di Provinsi Kalimantan Barat pada tahun 2019. Pemilihan unit analisis tersebut sesuai dengan tujuan utama penelitian, yaitu untuk menganalisis kemiskinan anak dengan membangun IKM Anak.

Tahap kedua yaitu menentukan dimensi dan indikator. Dimensi dan indikator yang digunakan diadopsi dari pendekatan MODA yang sebelumnya telah digunakan oleh BPS, OPHI, dan UNICEF dalam menganalisis deprivasi hak-hak dasar anak di Indonesia sebagaimana yang ditunjukkan pada TABEL 1 . 
TABEL 1. Dimensi dan Indikator Pembentuk IKM Anak

\begin{tabular}{|c|c|c|c|c|}
\hline No. & Dimensi & Indikator & Cut off & Sumber Referensi \\
\hline 1. & Perumahan & Luas lantai per kapita & $\begin{array}{l}\text { Anak yang tinggal di rumah dengan luas } \\
\text { lantai per kapita }<7,2 \mathrm{~m}^{2}\end{array}$ & BPS \\
\hline \multirow[t]{3}{*}{2.} & Fasilitas & Air minum bersih & $\begin{array}{l}\text { Anak yang tidak memiliki akses terhadap } \\
\text { sumber air minum layak }\end{array}$ & OPHI \\
\hline & & Sanitasi layak & $\begin{array}{l}\text { Anak yang tidak memiliki akses terhadap } \\
\text { fasilitas sanitasi layak }\end{array}$ & OPHI \\
\hline & & $\begin{array}{l}\text { Bahan bakar utama } \\
\text { memasak }\end{array}$ & $\begin{array}{l}\text { Anak yang tinggal di rumah tangga yang } \\
\text { memasak menggunakan bahan bakar alami }\end{array}$ & OPHI \\
\hline \multirow[t]{2}{*}{3.} & $\begin{array}{l}\text { Makanan dan } \\
\text { Nutrisi }\end{array}$ & Konsumsi kalori & $\begin{array}{l}\text { Anak dengan konsumsi kalori kurang dari } \\
\text { nilai MDER }\end{array}$ & BPS \\
\hline & & Pemberian ASI & $\begin{array}{l}\text { Anak yang tidak diberikan ASI eksklusif } \\
\text { atau makanan tambahan }\end{array}$ & UNICEF \\
\hline \multirow[t]{2}{*}{4} & Pendidikan & Partisipasi sekolah & Anak yang tidak sekolah & OPHI \\
\hline & & $\begin{array}{l}\text { Partisipasi sekolah } \\
\text { sesuai umur }\end{array}$ & $\begin{array}{l}\text { Anak yang bersekolah pada kelas/jenjang } \\
\text { yang lebih lambat dari umurnya }\end{array}$ & OPHI \\
\hline \multirow[t]{3}{*}{5} & $\begin{array}{l}\text { Perlindungan } \\
\text { Anak }\end{array}$ & $\begin{array}{l}\text { Kepemilikan akta } \\
\text { kelahiran }\end{array}$ & Anak yang tidak memiliki akta kelahiran & BPS \\
\hline & & Pernikahan usia anak & $\begin{array}{l}\text { Anak yang berstatus kawin atau pernah } \\
\text { kawin }\end{array}$ & BPS \\
\hline & & $\begin{array}{l}\text { Partisipasi pekerja } \\
\text { anak }\end{array}$ & $\begin{array}{l}\text { Anak yang bekerja atau membantu mencari } \\
\text { penghasilan selama seminggu terakhir }\end{array}$ & BPS \\
\hline 6 & Kesehatan & Imunisasi lengkap & $\begin{array}{l}\text { Anak yang tidak mendapatkan imunisasi } \\
\text { lengkap }\end{array}$ & UNICEF \\
\hline
\end{tabular}

Tahap selanjutnya ialah menentukan cut off deprivasi $(z j)$ per indikator. Cut off deprivasi $(z j)$ dibutuhkan untuk menentukan status terdeprivasi anak pada setiap indikator. Seorang anak dikatakan terdeprivasi pada indikator ke-j apabila pencapaiannya pada indikator tersebut berada di bawah cut off deprivasi.

Tahap berikutnya adalah menentukan penimbang (weight) per indikator yang didasarkan pada hasil uji robustness terhadap beberapa alternatif penimbang. Setelah diperoleh penimbang terbaik, lalu dilakukan perhitungan nilai (score) deprivasi pada setiap unit analisis. Adapun formulanya adalah sebagai berikut:

$$
c_{i}=w_{1} g_{i 1}^{0}+w_{2} g_{i 2}^{0}+\cdots+w_{13} g_{i 12}^{0}=\sum_{j=1}^{12} w_{j} g_{i j}^{0}
$$

Keterangan:

$c_{i} \quad=$ skor deprivasi individu ke-i

$g_{i j}^{0} \quad=$ status deprivasi individu ke-i pada indikator ke-j $G_{i j}^{0}=1$ jika $x_{i j}<z_{j}$ dan $g_{i j}^{0}=0$ jika

$$
x_{i j} \geq z_{j} \text { ) }
$$

$w_{j} \quad=$ Penimbang indikator ke-j dengan $\sum_{j=1}^{12} w_{j}=1$

Selanjutnya, menentukan cut off kemiskinan. Cut off kemiskinan merupakan suatu batasan yang digunakan untuk menentukan status kemiskinan multidimensi seseorang untuk menentukan status kemiskinan unit analisis. Dalam hal ini, ukuran cut off kemiskinan tersebut dibandingkan dengan skor deprivasi (ci) masing-masing individu. Seseorang dikatakan miskin secara multidimensi apabila nilai skor deprivasinya lebih dari sama dengan poverty cut off $(\mathrm{Ci} \geq k)$. Dalam konsep IKM oleh AlkireFoster (2013), seseorang dikatakan miskin multidimensi apabila skor deprivasinya lebih dari sama dengan $1 / 3$. 
Tahap selanjutnya adalah perhitungan Indeks Kemiskinan Multidimensi (IKM) Anak. IKM Anak menyatakan rata-rata deprivasi tertimbang yang dialami oleh penduduk usia 0 sampai 17 tahun pada suatu wilayah. Penghitungan IKM anak dilakukan menggunakan berikut:

$$
\begin{aligned}
I K M & =H \times A \\
H & =\frac{q}{n} \\
A & =\frac{\sum_{i=1}^{n} \sigma_{l}(k)}{q}
\end{aligned}
$$

Keterangan:

IKM = Indeks Kemiskinan Multidimensi

$\mathrm{H} \quad=$ Headcount ratio

A $\quad=$ Intensitas kemiskinan

$q \quad=$ Jumlah individu yang dikategorikan miskin multidimensi

$c_{i}(k)=$ Skor deprivasi dari individu miskin multidimensi ke-i

\section{Penentuan Penimbang Terbaik berdasarkan Uji Robustness}

Penentuan penimbang terbaik dari beberapa alternatif penimbang indikator dilakukan dengan melihat kekokohan (robustness) atau ketahanan peringkat IKM Anak terhadap perubahan penimbang yang diberikan. Hal tersebut mengacu pada uji robustness yang telah dilakukan oleh Alkire (2013), yaitu dengan melihat ketahanan peringkat IKM terhadap perubahan penimbang dimensi atau indikator.

Menurut Decanq dan Lugo (2012), pemberian penimbang pada indikator atau dimensi dapat dilakukan dengan beberapa metode, antara lain equal weights (pemberian bobot yang sama besar pada setiap dimensi atau indikator) dan data-driven weighting schemes (penimbang per indikator atau dimensi diperoleh berdasarkan karakteristik data yang tersedia). Pendekatan yang dapat dilakukan melalui metode data-driven weighting schemes yaitu Frequency-based Weights, Principal Component Analysis (PCA), dan Factor Analysis (FA). Oleh karena jenis data dari indikator yang digunakan bersifat dikotomi, maka dalam menghitung penimbang untuk pendekatan PCA maupun FA digunakan matrik korelasi tetrachoric. Korelasi tetrachoric adalah teknik korelasi yang digunakan apabila dua variabel yang dikorelasikan sama-sama merupakan variabel dikotomi (Vogt, 2015).

Selanjutnya, penentuan penimbang terbaik berdasarkan uji robustness dilakukan dengan melihat nilai korelasi rank Spearman. Semakin tinggi korelasi yang dihasilkan, semakin kokoh (robust) indeks yang dihasilkan terhadap perubahan parameter yang terjadi. Adapun formula penghitungan korelasi rank Spearman (Lobo and Guntur, 2018) adalah sebagai berikut:

$$
r_{S}=\frac{6 \sum_{i=1}^{n} d_{i}^{2}}{n\left(n^{2}-1\right)}
$$

$$
\begin{aligned}
& \text { Keterangan: } \\
& r_{S}=\text { Korelasi rank Spearman } \\
& r_{a}=\text { Peringkat (rank) kombinasi IKM a } \\
& r_{b}=\text { Peringkat (rank) kombinasi IKM b } \\
& d_{i}=r_{a}-r_{b} \\
& n=\text { Jumlah sampel } \\
& i=1,2,3, \ldots, \mathrm{n}
\end{aligned}
$$




\section{Kontribusi Dimensi dan Indikator}

Kontribusi dimensi dan indikator menunjukkan seberapa besar peran dimensi dan indikator dalam menentukan seorang individu dikategorikan sebagai individu miskin multidimensi. Penghitungan kontribusi dimensi dan indikator melibatkan censored headcount ratio $\left(h_{i}(k)\right.$ ), yaitu proporsi individu yang teridentifikasi sebagai individu miskin multidimensi $\left(c_{i} \geq k\right)$ dan sekaligus terdeprivasi pada dimensi atau indikator yang akan dihitung kontribusinya (Alkire and Santos, 2013).

$$
\begin{aligned}
\emptyset_{i}(k) & =w_{i} \frac{h_{i}(k)}{M_{0}} \\
M_{0} & =\sum_{i=1}^{12} w_{i} h_{i}(k)
\end{aligned}
$$

Keterangan:

$\emptyset_{i}(k)=$ Persentase kontribusi dari indikator $i$ pada cut off $k$

$w_{i} \quad=$ Penimbang indikator $i$

$h_{i}(k)=$ Censored headcount ratio

\section{HASIL DAN PEMBAHASAN}

Anak merupakan kelompok masyarakat yang paling rentan terkena imbas kemiskinan. Kemiskinan anak bukan hanya terbatas pada tidak terpenuhinya kebutuhan dasar anak dari aspek moneter saja, namun mencakup aspek yang lebih luas dan bersifat multidimensi, seperti kesehatan, pendidikan, dan aspek lainnya.

Penelitian ini mengkaji kemiskinan anak yang ditinjau dari banyak dimensi. Adapun unit analisis dalam penelitian ini adalah penduduk usia 0 sampai 17 tahun yang tinggal di Kalimantan Barat pada tahun 2019. Penelitian ini mencakup 12 indikator dari 6 dimensi yang diadopsi dari dimensi Multiple Overlapping Deprivation Analysis (MODA) oleh UNICEF dalam menganalisis deprivasi hak-hak dasar anak.

Penentuan status deprivasi seorang anak dilakukan dengan membandingkan karakteristik yang dimiliki oleh anak berdasarkan setiap indikator yang telah ditentukan dengan suatu ambang batas (cut off) yang selanjutnya disebut cut off deprivasi. Adapun gambaran deprivasi anak pada multidimensi di Kalimantan Barat ditunjukkan pada GAMBAR 1.

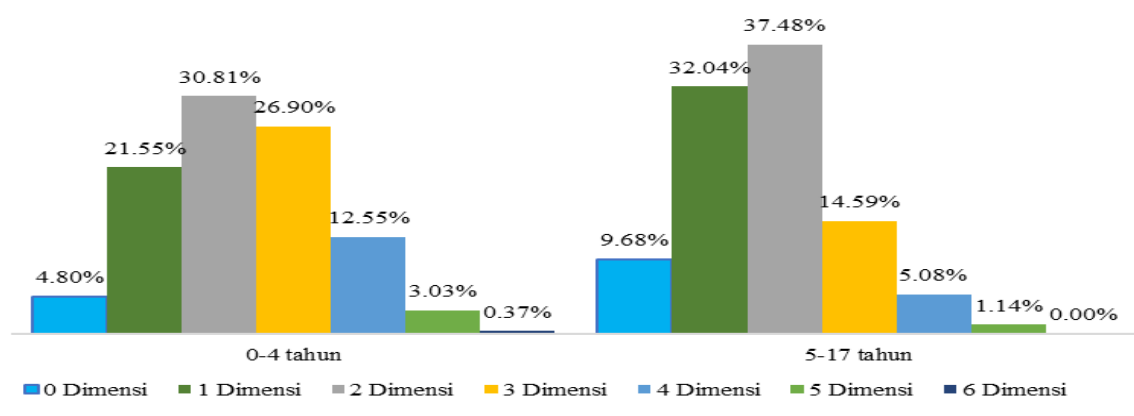

GAMBAR 1. Persentase anak yang terdeprivasi menurut jumlah dimensi dan kelompok umur.

Berdasarkan GAMBAR 1 diketahui bahwa mayoritas anak di Kalimantan Barat baik pada kelompok umur 0-4 tahun maupun 5-17 tahun mengalami deprivasi pada 2 atau 3 dimensi dan hanya sebagian kecil yang mengalami deprivasi pada 5 atau 6 dimensi. Selain itu, persentase anak usia 0-4 tahun yang tidak terdeprivasi lebih kecil dibandingkan dengan anak usia 5-17 tahun, yaitu 4,80 persen berbanding 9,68 persen. 


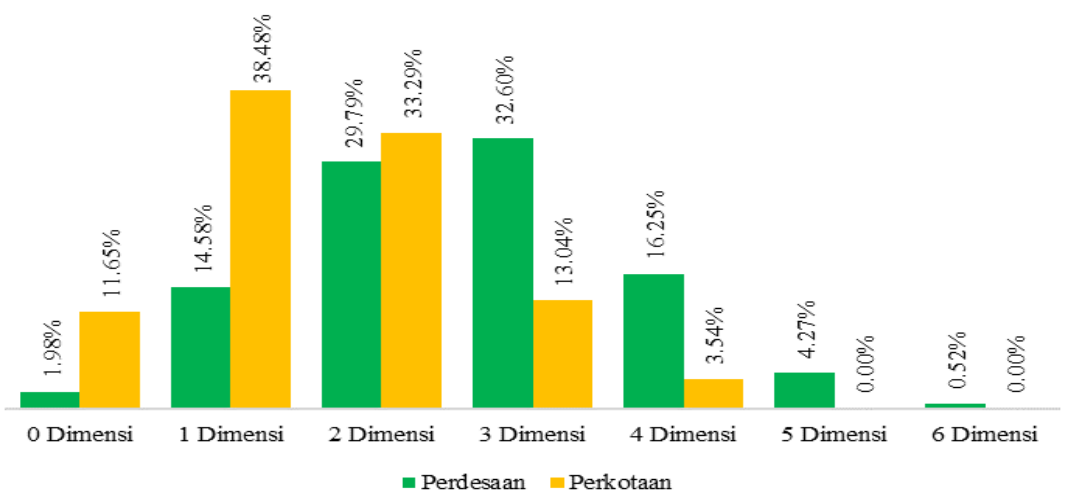

GAMBAR 2. Persentase anak usia 0-4 tahun yang terdeprivasi menurut jumlah dimensi dan tipe daerah.

Berdasarkan GAMBAR 2 dapat diketahui bahwa anak usia 0-4 tahun yang tinggal di daerah perdesaan sebagian besar mengalami deprivasi pada 3 dimensi, yaitu sebesar 32,60 persen. Sementara itu, anak yang tinggal di daerah perkotaan sebagian besar mengalami deprivasi pada 1 dimensi, yaitu sebesar 38,48 persen. Jika dibandingkan, anak yang tinggal di perdesaan lebih terdeprivasi pada jumlah dimensi yang lebih banyak dibandingkan dengan anak yang tinggal di perkotaan. Hal tersebut terlihat pada persentase terdeprivasi anak perdesaan yang lebih tinggi dibandingkan dengan anak di perkotaan seiring dengan bertambahnya jumlah dimensi yang terdeprivasi.

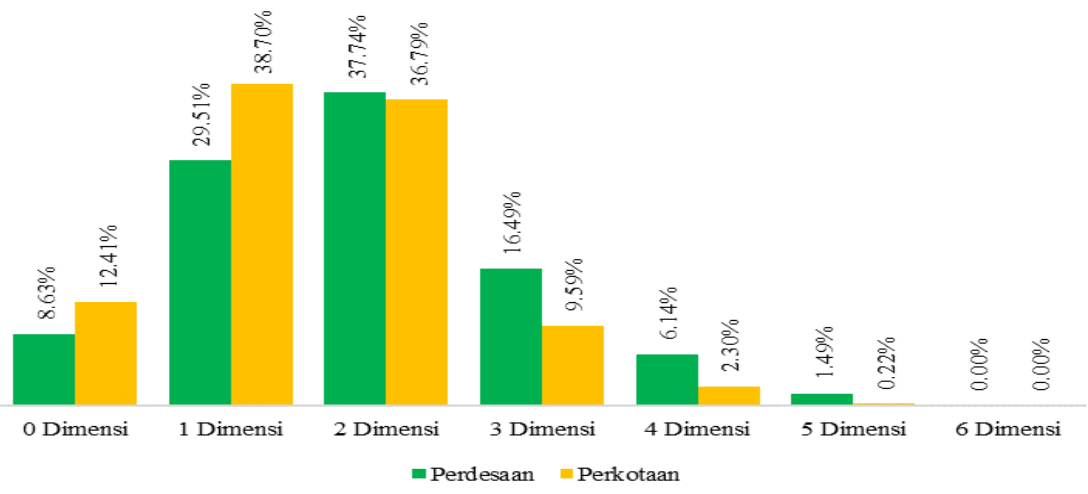

GAMBAR 3. Persentase anak usia 5-17 tahun yang terdeprivasi menurut jumlah dimensi dan tipe daerah.

Berdasarkan GAMBAR 3, anak yang tinggal di daerah perdesaan paling banyak mengalami deprivasi pada 2 dimensi, yaitu sebesar 37,74 persen. Sementara itu, anak yang tinggal di daerah perkotaan paling banyak mengalami deprivasi pada 1 dimensi, yaitu sebesar 38,70 persen. Sama halnya dengan anak usia 0-4 tahun, anak usia 5-17 tahun yang tinggal di perdesaan lebih terdeprivasi pada jumlah dimensi yang lebih banyak dibandingkan dengan anak yang tinggal di perkotaan. Hal tersebut terlihat pada persentase terdeprivasi anak perdesaan yang lebih tinggi dibandingkan dengan anak di perkotaan seiring dengan bertambahnya jumlah dimensi yang terdeprivasi.

Selanjutnya menghitung IKM Anak antarkombinasi penimbang dimensi, lalu menentukan penimbang terbaik berdasarkan uji robustness menggunakan korelasi rank Spearman. Berikut ini adalah hasil korelasi rank Spearman IKM Anak berdasarkan kombinasi penimbang dimensi/indikator yang diajukan. 
TABEL 2. Nilai korelasi rank Spearman IKM Anak antarkombinasi penimbang dimensi.

\begin{tabular}{ccccccccc}
\hline & IKM A & IKM B & IKM C & IKM D & IKM E & IKM F & IKM G & IKM H \\
\hline IKM A & 1,000 & $0,960^{*}$ & $0,899^{*}$ & $0,859^{*}$ & $0,969^{*}$ & $0,776^{*}$ & $0,798^{*}$ & $0,952^{*}$ \\
IKM B & $0,960^{*}$ & 1,000 & $0,903^{*}$ & $0,881^{*}$ & $0,943^{*}$ & $0,837^{*}$ & $0,780^{*}$ & $0,934^{*}$ \\
IKM C & $0,899^{*}$ & $0,903^{*}$ & 1,000 & $0,829^{*}$ & $0,934^{*}$ & $0,644^{*}$ & $0,741^{*}$ & $0,899^{*}$ \\
IKM D & $0,859^{*}$ & $0,881^{*}$ & $0,829^{*}$ & 1,000 & $0,833^{*}$ & $0,780^{*}$ & $0,613^{*}$ & $0,855^{*}$ \\
IKM E & $0,969^{*}$ & $0,943^{*}$ & $0,934^{*}$ & $0,833^{*}$ & 1,000 & $0,727^{*}$ & $0,714^{*}$ & $0,921^{*}$ \\
IKM F & $0,776^{*}$ & $0,837^{*}$ & $0,644^{*}$ & $0,780^{*}$ & $0,727^{*}$ & 1,000 & $0,525^{*}$ & $0,723^{*}$ \\
IKM G & $0,798^{*}$ & $0,780^{*}$ & $0,741^{*}$ & $0,613^{*}$ & $0,714^{*}$ & $0,525^{*}$ & 1,000 & $0,855^{*}$ \\
IKM H & $0,952^{*}$ & $0,934^{*}$ & $0,899^{*}$ & $0,855^{*}$ & $0,921^{*}$ & $0,723^{*}$ & $0,855^{*}$ & 1,000 \\
\hline Rata-rata & $\mathbf{0 , 9 0 2}$ & $\underline{\mathbf{0 , 9 0 5}}$ & $\mathbf{0 , 8 5 6}$ & $\mathbf{0 , 8 3 1}$ & $\mathbf{0 , 8 8 0}$ & $\mathbf{0 , 7 5 2}$ & $\mathbf{0 , 6 2 8}$ & $\mathbf{0 , 8 9 2}$ \\
\hline
\end{tabular}

*) Korelasi signifikan pada tingkat signifikansi 5 persen

\section{Keterangan:}

A, B: Equal weights

C, D, E, F: Frequency-based weights

G: Principal Component Analysis (PCA)

$\mathrm{H}$ : Factor Analysis (FA)

Berdasarkan TABEL 2, diketahui bahwa kombinasi penimbang dengan rata-rata korelasi terbesar adalah kombinasi penimbang B atau equal weights, yaitu kombinasi penimbang dengan pemberian bobot yang sama untuk setiap dimensi pembentuk IKM Anak. Penimbang tersebut selanjutnya dipilih sebagai penimbang untuk menghitung IKM Anak Kalimantan Barat beserta IKM Anak di setiap kabupaten/kota di Kalimantan Barat. Adapun nilai IKM Anak berdasarkan penimbang terbaik ditunjukkan pada GAMBAR 4 berikut.

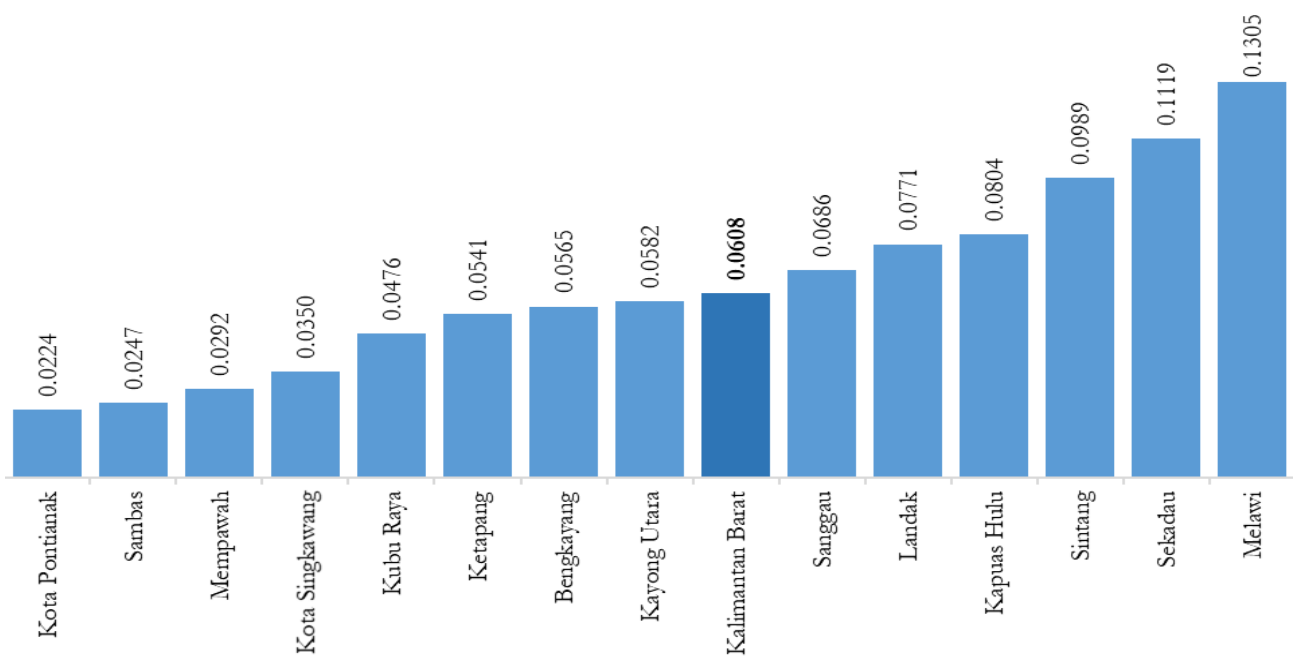

GAMBAR 4. IKM Anak menurut kabupaten/kota di Provinsi Kalimantan Barat.

Berdasarkan GAMBAR 4, diketahui bahwa besarnya IKM Anak di Provinsi Kalimantan Barat adalah 0,0608, dengan headcount ratio sebesar 0,1487 dan intensitas sebesar 0,4088. Artinya, sebanyak 14,87 persen anak di Kalimantan Barat miskin secara multidimensi dengan rata-rata deprivasi yang dialami adalah 40,88 persen dari 12 indikator penyusun IKM Anak. Nilai IKM Anak 0,0608 berarti rata-rata deprivasi yang dialami oleh seluruh anak di Kalimantan Barat adalah 6,08 persen dari 12 indikator penyusun IKM Anak.

Dari ke-14 kabupaten/kota di Kalimantan Barat, IKM Anak tertinggi terdapat di Kabupaten Melawi, yaitu sebesar 0,1305 dengan headcount ratio sebesar 0,3021 dan intensitas sebesar 0,4320. 
Artinya, 30,21 persen anak di Melawi dikategorikan sebagai anak miskin multidimensi dan rata-rata deprivasi yang dialami anak miskin tersebut adalah 43,20 persen dari 12 indikator penyusun IKM Anak. Beberapa kabupaten lain dengan nilai IKM Anak tertinggi di antaranya Kabupaten Sekadau, Sintang, dan Kapuas Hulu.

Selanjutnya dilakukan uji validitas terhadap IKM Anak yang diperoleh. Validitas dapat diartikan sebagai tingkat kebaikan ukuran yang telah dihasilkan dalam mengukur karakteristik yang akan diukur. Dalam hal ini, ukuran IKM Anak dianggap valid apabila dapat dibandingkan dengan suatu ukuran referensi. Pada penelitian ini, uji validitas dilakukan dengan membandingkan pola serta nilai korelasi rank antara IKM Anak dan IPM yang dihasilkan oleh BPS.

Hasil korelasi rank Spearman menunjukkan bahwa ukuran IKM Anak dan IPM memiliki korelasi kuat dan signifikan, yaitu sebesar -0,554. Tanda negatif menunjukkan hubungan antara kemiskinan dan pembangunan. Penyajian perbandingan antara IKM Anak dan IPM dalam bentuk peta tematik dapat dilihat pada GAMBAR 5.

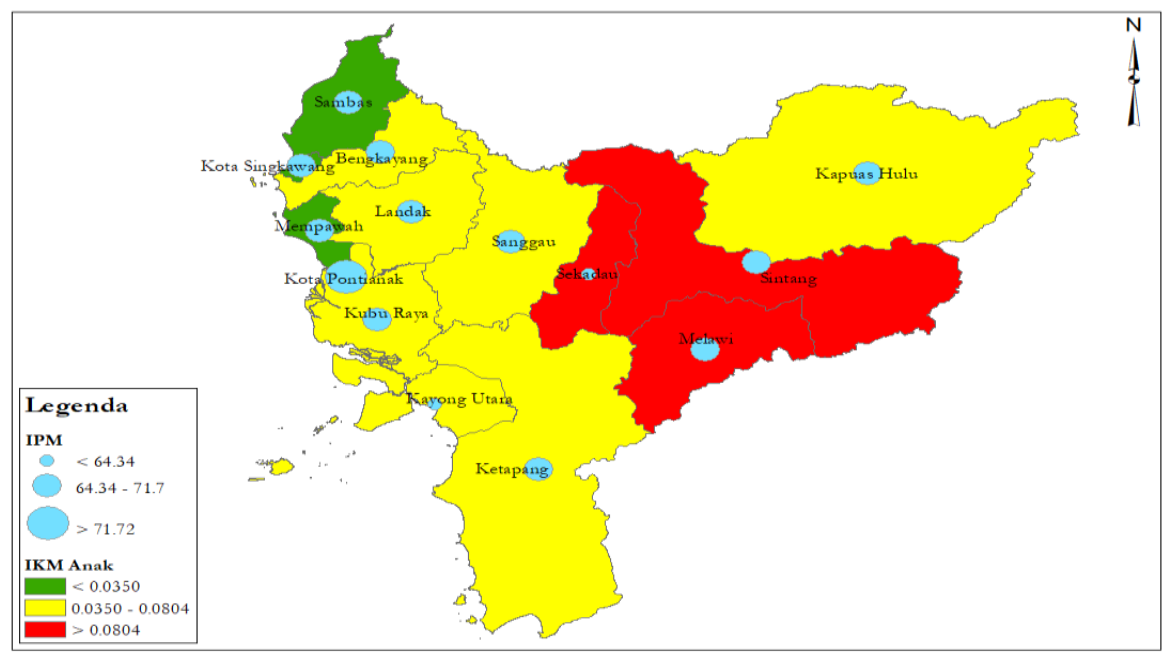

GAMBAR 5. IKM Anak menurut kabupaten/kota di Provinsi Kalimantan Barat.

Berdasarkan GAMBAR 5, dapat dilihat bahwa hasil penghitungan IKM Anak menunjukkan pola yang berkebalikan dengan IPM. Wilayah dengan kategori IKM Anak yang tinggi cenderung memiliki IPM dengan kategori rendah, begitu pula sebaliknya. Dengan demikian, dapat disimpulkan bahwa ukuran IKM Anak yang telah dihasilkan dapat digunakan sebagai indikator alternatif dalam mengukur pembangunan manusia di Kalimantan Barat.

Selanjutnya dilakukan perhitungan kontribusi dimensi dan indikator terhadap kemiskinan anak di Kalimantan Barat menggunakan Persamaan 6. Persentase kontribusi masing-masing dimensi dan indikator terhadap kemiskinan anak ditunjukkan pada GAMBAR 6 berikut.

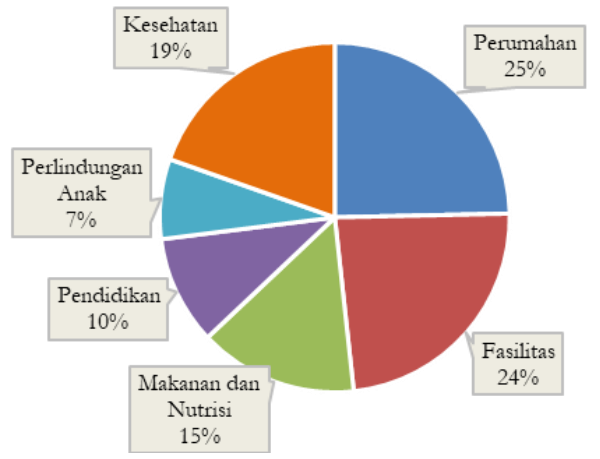

(a)

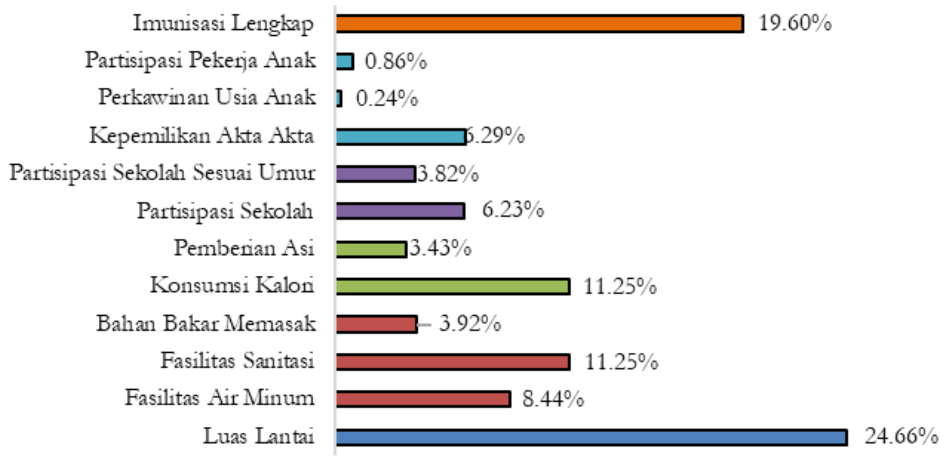

(b)

GAMBAR 6. Kontribusi Dimensi dan Indikator. 
Berdasarkan GAMBAR 6, diketahui bahwa dimensi dengan persentase kontribusi terbesar adalah dimensi perumahan yaitu sebesar 25 persen, diikuti oleh dimensi fasilitas, yaitu sebesar 20,43 persen. Sementara itu, dimensi perlindungan anak adalah dimensi dengan persentase kontribusi terkecil, yaitu 5,97 persen. Apabila dilihat menurut indikator dapat diketahui bahwa indikator dengan kontribusi terbesar adalah luas lantai perkapita, yaitu sebesar 24,66 persen. Sedangkan indikator dengan kontribusi terkecil adalah perkawinan usia anak, yaitu sebesar 0,24 persen.

Setelah diketahui dimensi dan indikator yang paling berkontribusi tehadap kemiskinan anak di Kalimantan Barat, selanjutnya dilakukan analisis lanjutan untuk mengetahui wilayah yang perlu menjadi prioritas pengentasan kemiskinan berdasarkan klasifikasi kuadran. Hasil pengelompokkan wilayah berdasarkan klasifikasi kuadran ditunjukkan pada GAMBAR 7 berikut.

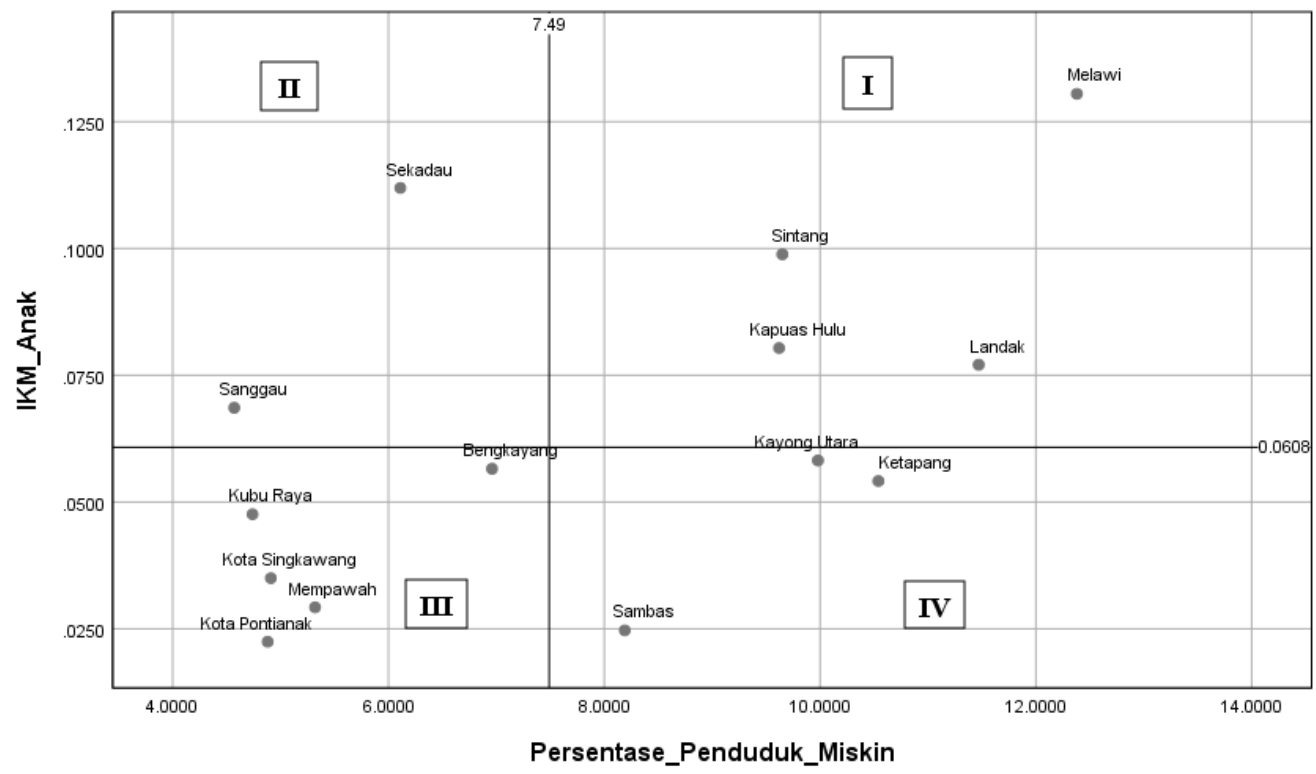

GAMBAR 7. Klasifikasi kuadran kabupaten/kota berdasarkan persentase penduduk miskin dan IKM Anak.

GAMBAR 7 menunjukkan klasifikasi kuadran dari kabupaten/kota di Kalimantan Barat berdasarkan persentase penduduk miskin dan IKM Anak. Berdasarkan sebaran titik yang dihasilkan, terlihat bahwa secara umum terdapat hubungan yang positif antara persentase penduduk miskin dan IKM Anak, artinya kabupaten/kota dengan persentase penduduk miskin yang tinggi cenderung untuk memiliki IKM Anak yang tinggi, begitu pula sebaliknya. Informasi mengenai kabupaten/kota mana saja yang termasuk ke dalam masing-masing kuadran disajikan pada TABEL 3.

TABEL 3. Dimensi dan Indikator Pembentuk IKM Anak.

\begin{tabular}{cll}
\hline & \multicolumn{1}{c}{ Kuadran } & \multicolumn{1}{c}{ Kabupaten/Kota } \\
\hline I $\quad \begin{array}{l}\text { Wilayah dengan persentase penduduk miskin di } \\
\text { bawah angka provinsi tetapi IKM Anak di atas angka } \\
\text { provinsi }\end{array}$ & $\begin{array}{l}\text { Landak, Sintang, Kapuas Hulu, } \\
\text { dan Melawi }\end{array}$ \\
II $\quad \begin{array}{l}\text { Wilayah dengan persentase penduduk miskin dan } \\
\text { IKM Anak di atas angka provinsi }\end{array}$ & Sanggau dan Sekadau \\
& $\begin{array}{l}\text { Wilayah dengan persentase penduduk miskin dan } \\
\text { IKM Anak di bawah angka provinsi }\end{array}$ & $\begin{array}{l}\text { Bengkayang, Mempawah, Kubu } \\
\text { Raya, Kota Pontianak dan Kota } \\
\text { Singkawang }\end{array}$ \\
& $\begin{array}{l}\text { Wilayah dengan persentase penduduk miskin di atas } \\
\text { angka provinsi tetapi IKM Anak di bawah angka } \\
\text { provinsi }\end{array}$ & $\begin{array}{l}\text { Sambas, Ketapang, dan Kayong } \\
\text { Utara }\end{array}$ \\
\hline
\end{tabular}


Berdasarkan informasi pada TABEL 3, dapat disimpulkan bahwa wilayah yang memerlukan prioritas utama adalah kabupaten/kota yang berada pada kuadran I. Anak-anak yang berada pada wilayah tersebut memiliki tantangan yang lebih besar untuk dapat keluar dari kemiskinan karena keterbatasan baik dari aspek moneter maupun non moneter.

\section{KESIMPULAN DAN SARAN}

\section{Kesimpulan}

Berdasarkan hasil dari penelitian ini ditemukan bahwa sebagian besar anak di Kalimantan Barat terdeprivasi pada 2 dan 3 dimensi. Secara umum, anak yang lebih banyak terdeprivasi adalah mereka yang tinggal di daerah perdesaan. Nilai IKM Anak di Provinsi Kalimantan Barat adalah 0,0608, dengan headcount ratio sebesar 0,1487 dan intensitas sebesar 0,4088. Artinya, rata-rata deprivasi yang dialami oleh seluruh anak di Kalimantan Barat adalah 6,08 persen dari 12 indikator penyusun IKM Anak. Adapun nilai headcount ratio sebesar 0,1487 dan intensitas sebesar 0,4088 berarti terdapat sekitar 14,87 persen anak di Kalimantan Barat miskin multidimensi dengan rata-rata deprivasi yang dialami adalah 40,88 persen dari 12 indikator pembentuk IKM Anak. Sementara itu, wilayah dengan IKM Anak tertinggi di Kalimantan Barat, antara lain Kabupaten Melawi, Sekadau, Sintang, dan Kapuas Hulu. Selanjutnya, dimensi yang paling besar berkontribusi terhadap kemiskinan anak di Kalimantan Barat adalah dimensi perumahan, yaitu sebesar 25 persen. Kemudian, berdasarkan hasil klasifikasi kuadran diperoleh wilayah yang perlu menjadi prioritas utama dalam upaya pengentasan kemiskinan berkelanjutan adalah Kabupaten Landak, Sintang, Kapuas Hulu, dan Melawi.

\section{Saran}

Untuk penelitian selanjutnya, sebaiknya menambahkan indikator lain yang belum ada misalnya anak putus sekolah, kasus kekerasan terhadap anak, angka kesakitan anak, dan sebagainya agar diperoleh gambaran kemiskinan anak yang lebih komprehensif

\section{UCAPAN TERIMA KASIH}

Penulis mengucapkan terima kasih kepada BPS Provinsi Kalimantan Barat serta BPS Kabupaten Sekadau yang telah menyediakan data untuk penelitian ini. Selanjutnya, penulis juga berterima kasih kepada pihak-pihak yang telah ikut menyumbang ide, saran, dan dukungan sehingga penelitian ini dapat dilakukan sebagaimana mestinya.

\section{REFERENSI}

Alkire, S. and Santos, M. E. (2013) 'A Multidimensional Approach: Poverty Measurement \& Beyond', Social Indicators Research. doi: 10.1007/s11205-013-0257-3.

Badan Pusat Statistik (2017) Analisis Kemiskinan Anak dan Deprivasi Hak-Hak Dasar Anak di Indonesia. Jakarta: Badan Pusat Statistik.

Decancq, K. and Lugo, M. A. (2012) 'Weights in Multidimensional Indices of Wellbeing: An Overview', Econometric Reviews. doi: 10.1080/07474938.2012.690641.

Kurukulasuriya, S. and Engilbertsdottir, S. (2011) 'A Multidimensional Approach to Measuring Child Poverty', (February), p. $8 . \quad$ Available at: https://www.unicef.org/socialpolicy/files/A_Multidimensional_Approach_to_Measuring_Child_P overty(2).pdf.

Lobo, M. and Guntur, R. D. (2018) 'Spearman's rank correlation analysis on public perception toward health partnership projects between Indonesia and Australia in East Nusa Tenggara Province', Journal of Physics: Conference Series, 1116(2). doi: 10.1088/1742-6596/1116/2/022020. 
Milliano, M. de and Handa, S. (2014) 'Child poverty and deprivation in Mali', Archives of Disease in Childhood, 66(10), pp. 1255-1257. Available at: http://ovidsp.ovid.com/ovidweb.cgi?T=JS\&PAGE=reference\&D=emed2\&NEWS=N\&AN=1991 321535 .

Neubourg, C. De et al. (2012) 'Step-by-Step Guidelines to the Multiple Overlapping Deprivation Analysis ( MODA )', (December), p. 40. Available at: https://ideas.repec.org/cgi-

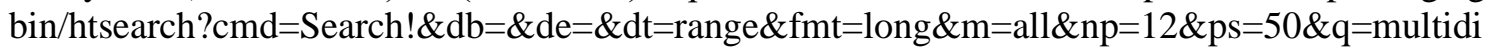
mensional+poverty\&s=R\&sy=1\&ul=\&wf=4BFF\%5Cnhttp://files/1745/Neubourg et al. - 2013 Step-by-Step Guidelines to the Multiple Overlappin.pdf\%5Cnhttp:/.

Panuluh, S. and Fitri, M. R. (2016) 'Perkembangan Pelaksanaan Sustainable Development Goals (SDGs) di Indonesia', Biefing Paper 02, infid(Sustainable Development Goals (SDGs)), pp. 125. Available at: http://www.sdg2030indonesia.org/an-component/media/uploadbook/Briefing_paper_No_1_SDGS_-2016-Meila_Sekar.pdf.

Sedgwick, P. (2014) 'Spearman's rank correlation coefficient', BMJ (Online), 349(November), pp. 13. doi: $10.1136 / \mathrm{bmj} . \mathrm{g} 7327$.

Sen, A. (1981) Poverty and Famines: An Essay on Entitlement and Deprivation. New York: Oxford University Press. doi: 10.2307/3517051.

UNICEF (2016) 'Ending Extreme Poverty: A Focus on Children'. Available at: https://www.unicef.org/publications/index_92826.html.

Vogt, W. (2015) 'Tetrachoric Correlation', Dictionary of Statistics \& Methodology, pp. 429-437. doi: 10.4135/9781412983907.n1966. 